Colonialism and the Politics of 'Chinese History' in Hong Kong's Schools

Edward Vickers

Flora Kan

Paul Morris

(1) 


\section{Notes on Contributors}

Edward Vickers, Textbook Author and Independent Scholar

Flora Kan, Assistant Professor, Department of Curriculum Studies, The University of Hong Kong

Paul Morris, Deputy Director (Academic), Hong Kong Institute of Education 


\title{
Colonialism and the Politics of 'Chinese History' in Hong Kong's Schools
}

\begin{abstract}
Writers on colonial education have generally assumed that colonial curricula were tools of metropolitan political and cultural 'hegemony'. In particular, it is alleged that colonial history curricula neglected or ignored the histories of indigenous populations. Through analysing the case of Chinese History in Hong Kong, this article demonstrates that these assumptions are highly misleading. Far from exercising 'hegemonical' authority over the school curriculum, the colonial government was to a large extent the prisoner of its local collaborators. For reasons of political as well as educational expediency, in the post-war years the government initiated a conservative Chinese History curriculum to be taught alongside the separate subject of 'History'. Subsequently, a strong Chinese History subject community evolved, who by appealing to nationalist sentiment were able to successfully resist the calls for reform. As a result, efforts by both the colonial and post-colonial administrations to resolve the anomaly of having two history subjects have proved fruitless.
\end{abstract}




\section{Colonialism and the Politics of 'Chinese History' in Hong Kong's Schools}

\section{$\underline{\text { Introduction }}$}

History tends to be the most politically and culturally sensitive of all school subjects, particularly because of the way it relates to an often highly politicised public discourse over national identity. For example, Slater (1989), Husbands and Pendry (1992), Phillips (1998) and Goodson (1994) have all noted that the subject of history has in recent years become the focus of political controversy in a number of Western countries. However these authors have differed in their assessment of the motivations and relative influences of politicians, the media, the History 'subject community' and other major 'stakeholders' in the curriculum development process.

The research conducted on history curricula in 'the West', and particularly in the UK, has yet to be matched by similarly extensive and critical research into the development of history teaching in China or in Asia. Nonetheless, recent research by Vickers (2000) into the history of the school subject of 'History' in Hong Kong found that the expansion of schooling during the late colonial period, combined with rapid social and political change and exposure to overseas curricular models, contributed to a decisive shift in the subject culture - from a traditional academic emphasis, towards the promotion of a more skillsbased pedagogy. He therefore argued that the pattern posited by Goodson (1995) - whereby competition among subject communities for status leads inevitably to the adoption of an increasingly academic bent - has been inverted in the case of 'History' in Hong Kong.

This article discusses the political influences on the development, in Hong Kong, of the school subject 'Chinese History' - a subject which coexists but is distinct from 'History' We shall analyse the origins and persistence of this division of history into two separate subjects in the late colonial and post-retrocession periods. We hope to demonstrate and explain why the development of 'Chinese History' has conformed more to the pattern posited by Goodson, than to that identified by Vickers. We will argue that the explanation for this lies principally in the impact on the curriculum of the local political context, and that, in order to understand this context, a re-evaluation of the nature of colonialism in late twentieth century Hong Kong is required. We therefore critically examine prevailing conceptions of the role of colonialism in shaping curriculum policy in Hong Kong, with an emphasis on the significance of the return of sovereignty in 1997. 


\section{Colonialism and history education}

Attempt to generalize about the characteristics of colonial history curricula inevitably encounters the difficulty that little detailed research has been carried out on history curricula in other colonies. However, the absence of a body of research has not deterred scholars from making ambitious generalizations about 'colonial' education in general, and 'colonial' history teaching in particular. These assume that colonialism has involved a confrontation between two diametrically opposing cultural forces: on the one hand, the 'hegemonist' conspiracy of Western imperialism attempting to force indigenous societies into a position of cultural as well as economic dependency; and on the other, the 'authentic' indigenous cultures that have resisted this Western assault.

The classic exposition of the 'cultural imperialism' thesis was made by Carnoy (1974), who wrote that 'Western formal education [in colonies]... was consistent with the goals of imperialism: the economic and political control of the people in one country by the dominant class of another.' Similarly, Kelly and Altbach (1984) claimed that research on colonial education 'told us what those who ran the schools wished.... to accomplish - which, put quite simply, was to assist in the consolidation of foreign rule.' Said's much-cited works (1991, 1995) have reinforced and popularized an interpretation of the impact of Western culture on indigenous cultures, in Asia and elsewhere, as both overwhelming in its scale, and almost uniformly negative in its effects.

Meanwhile, other writers concerned with education, such as Meyer, Kamens and Benavot (1992), and Yun-kyung Cha (1992) have developed new variations on the 'cultural imperialism' theme, positing the existence of a 'Common World Educational Culture'. Yunkyung Cha argues that in the contemporary world:

\footnotetext{
'...the school curriculum is a ritual enactment of worldwide educational norms and conventions rather than instrumental choice of individual societies to meet various local requirements. The definition of legitimate knowledge to be taught in schools, and the selection and hierarchical organization of such bodies of knowledge are thus by and large "externally" prescribed.'(p. 65)
}

When colonial history curricula are alluded to by authors such as these, 'external prescription' and the devaluation of indigenous cultures are dominant themes. Altbach and Kelly (1978), for example, assert that: 
' History in the main, if it touched on the colonized's past, was only the history of the colonized since they were ruled by Europeans. If precolonial history was touched on, it usually emphasized, through chronology, civil wars, tribal conflicts, famines, and barbarism in order to contrast them with the peace and orderly progress under colonial domination.'(p. 14)

Said (1994) similarly portrays imperialism as a massive cultural conspiracy:

'The great colonial schools... taught generations of the native bourgeoisie important truths about history, science, culture. Out of that learning process millions grasped the fundamentals of modern life, yet remained subordinate dependents of an authority based elsewhere than in their lives. Since one of the purposes of colonial education was to promote the history of France or Britain, that same education also demoted the native history.'( pp. 269-270)

These perspectives on colonialism and education cannot adequately account for the nature and role of either Chinese History or History in the Hong Kong secondary school curriculum. Before analyzing the origins and development of the 'Chinese History' subject, we first propose an alternative theory of colonialism that better explains the context in which that development took place.

\section{Education and Hong Kong's collaborative politics - with or without 'colonialism'}

It may be objected, that late twentieth century Hong Kong was not a 'typical' colony, but this begs the questions of the nature of 'typical' colonialism. Gifford \& Weiskel (1971) and Asiwaju (1975) have demonstrated the varied nature of colonialism practiced by states such as Britain, Germany, Portugal and Holland. Furthermore, Robinson (1986) has argued that the stereotypical view of colonialism, that sees it purely in terms of the impact of an aggressively 'active' metropolis on an impotently 'passive' periphery, is fundamentally flawed. He points out that the force at the disposal of the colonizing powers was never sufficient, on its own, to maintain colonial dominance at a cost which would make the colonial enterprise worthwhile. Colonial governments therefore depended on a measure of collaboration from indigenous elites, the extent of which varied between colonies and over time.

From this perspective the fundamental distinction between Hong Kong and most other colonies is the extent to which the population was prepared to deepen and prolong the collaborative relationship with the colonizing power. That colonialism, in Hong Kong's case, 
did not end in independence during the era of decolonisation in the1950s and 1960s was a consequence not of British coercion, but of the acquiescence of both the government of the People's Republic of China (PRC) and of the local Chinese population in the continuance of British rule; the realization that the only realistic alternative to British rule was rule by communist China - from which most residents had fled during or after China's civil war (Lau, 1997). Nonetheless, serious riots in 1966 and 1967 underlined the fragility of British authority, and in particular the danger of antagonizing the PRC government, or of insensitivity or arrogance in the handling of_the local population. Colonial rule in late twentieth century Hong Kong was therefore characterized by extreme caution. As the Secretary of Home Affairs explained in 1974:

\footnotetext{
'We proceed by consensus rather than debate for this is the only course open to a government required to continue indefinitely in power. A government newly elected to power on the basis of a political programme can ride roughshod over even quite substantial minorities. This we cannot do here. Consensus implies consultation, negotiation and compromise on a scale that would be unacceptable to a party returned to power by election.' (C.K. Lau, 1997, p. 30).
}

The colonial government's aversion to controversy was nowhere more evident than in the field of education. The period from the late 1960s to early 1990s saw a rapid expansion of educational provision at the primary, secondary and tertiary levels successively and this was mainly motivated by the need to respond to social instability. However, quantitative expansion was not matched by qualitative change. The school curriculum remained essentially unchanged following the transition from a highly elitist system of secondary schooling to one of mass provision. Reform initiatives, for example, the use of Chinese as the medium of instruction and the Activity Approach, were seldom pursued with any determination, and compliance on the part of schools and teachers was optimal, for this would have been to invite non-compliance and opposition that could seriously embarrass the government.

However, by the late 1980s and early 1990s, a number of factors were conspiring to challenge this pattern of quantitative expansion accompanied by qualitative inertia. Among these was the growth of a local middle class, who proved more demanding as parents than the preceding generation. But, although social and economic developments led to greater pressure for curriculum reform, and especially for the adoption of more stimulating and 
'skills-oriented' approaches, of particular significance for the subjects of 'History' and 'Chinese History' were the repercussions of Hong Kong’s political transition.

Throughout this period the formal 'History' curriculum increasingly focussed on promoting skills and critical enquiry. This was evidenced by the introduction of data based questions and the study of local history. However, politically controversial issues were avoided. For example, the Education Department (ED), answering inquires from the South China Morning Post on 4 April 1986, stressed that 'this Department has always recommended that publishers should avoid controversial historical materials and biased wording' (Document kept in the Press Cutting File, History Section, Advisory Inspectorate, Education Department).

In avoiding the most politically controversial issues, curriculum developers were continuing a practice that had become ingrained in Hong Kong's bureaucratic culture. The impending transfer of sovereignty from Britain to China prompted a redefinition of 'controversial' content, but only within the parameters dictated by political prudence. However, the 1997 handover brought with it a rapid change in the government's handling of education policy. The new administration, under the Chief Executive Tung Chee Hwa, felt that it possessed the legitimacy that its colonial predecessor lacked, and was eager to use this authority to introduce sweeping reforms of the entire education system. First came a move from voluntarism to compulsion on the crucial issue of medium of instruction, shortly followed by other often radical and sometimes contradictory reform proposals. At the same time, the government has tried to circumvent the established policymaking process within the civil service, instead relying increasingly on the appointed members of the Education Commission (Morris et al., 2000).

A central element of the proposed reforms has been the promotion through the school curriculum of patriotic or national sentiment, representing a drastic break from the depoliticisation practised before 1997. This objective has been pursued through the new post-handover curricula for Putonghua and Civic Education - subjects which were ignored or neglected before 1997 - and through changes to the curriculum for Chinese History. Simultaneously, however, the introduction of Putonghua and 'Information Technology' as new compulsory subjects has led to increasingly crowded school timetables, and the resulting pressure to trim the curriculum has appeared to threaten the continued existence of Chinese History as an independent subject.

The fate of Chinese History has, since 1997, become central to the debate over the reform of the school curriculum. The controversy over its status along with the continuing 
controversies over medium of instruction policy and other aspects of the government's programme for education, has revealed how the new administration, like its colonial predecessor, possesses only the weakest of mandates, and is similarly dependent on collaboration with vocal and well-organised vested interests. The remainder of this article analyzes in greater depth the ways in which the origins and survival of Chinese History have reflected political change - and continuity - over the past half-century. A central theme of this discussion will be the relative weaknesses of both the colonial and post-colonial administrations, and the dependency of both on the collaboration of Hong Kong's educational and business, elites.

\section{The origins of 'Chinese History'}

British concerns regarding the role Chinese history could play in stirring up anticolonial sentiment predated World War II. Luk (1991) has shown how, as early as the 1920s, Governor Clementi was lending encouragement to conservative Chinese scholars opposed to the Nationalist regime in China, in the hope that they would devise a school curriculum characterised by a depoliticised, backward-looking culturalism that would prove an effective antidote to xenophobic nationalism in Hong Kong. In 1930, an official from the Colonial Office in London noted that in government schools 'special local conditions justified more attention being paid to ancient civilizations than to current events,' and commented that 'it is not considered desirable to interest Hong Kong students too much in political and administrative questions' (quoted in Sweeting, 1991). However, government involvement in the provision of Chinese-medium education remained minimal in the pre-war period, when the dictates of laissez-faire precluded large-scale spending on education, and when the bulk of the Chinese population consisted of labourers whose families remained in China. Until the 1950s, whenever the history of China was taught to local Chinese students in their own language, this was almost invariably done using textbooks published in mainland China.

In the aftermath of the Chinese Civil War and the Korean War, however, several factors made the Hong Kong government particularly jittery regarding the potential ramifications of teaching Chinese history. Firstly, by 1950 the colonial authorities were confronted with the novel reality of a Chinese regime with the military capacity to overpower the Hong Kong garrison. Henceforth, the preservation of British rule would depend upon the leaders in Beijing continuing to calculate that they would have more to lose than gain by ending Hong Kong's colonial status. Secondly, Hong Kong had become a 
massive refugee camp for those fleeing the conflict in China. Its role as an entrepot, dependent on migrant labour from the mainland, disappeared, and instead the swelling population found employment in new factories and businesses, many of them set up by exiled entrepreneurs from Shanghai. Many refugees were supporters of the defeated Nationalists, but there were also those who favoured the Communists. Street-fights frequently broke out, occasionally developing into more serious riots, such as those of 1956.

In this politically tense atmosphere, the government was anxious to extend its supervision of the school curriculum to ensure that inflammatory material was kept out of classrooms. To this end, in 1952 a Syllabus and Textbooks Committee was established within the Education Department, and a Chinese Studies Committee was formed to review the teaching of the Chinese language, history and culture. The following year, the latter committee produced a report in which the need for reform of Chinese history teaching was emphasised:

\footnotetext{
'History textbooks published in China usually contain anti-foreign allusions, comments and propaganda, and are, therefore, not quite suitable for use in Hong Kong... Here [Hong Kong], Chinese pupils can not only retain and cherish what is best in their own culture, but learn of what is best in British and World thought... In these textbooks, the emphasis should be on Social and Cultural History rather than Political History.' (Education Department 1953, p.31, italics added)
}

The report further elaborated the approach to the Chinese past considered appropriate by the committee:

'Before the Manchu Dynasty, China's weakness was arrogance. Since the end of that dynasty, she has, however, suffered from an inferiority complex, and tended to imitate other peoples, forgetting her own good points and virtues. Therefore, one purpose of teaching Chinese History to Chinese children would be to get rid of this complex by reviving what is good in Chinese culture, thereby instilling fresh confidence into, and restoring the self-respect of, her people. This, however, must not be identified with the promotion of anti-foreignism, which is to be strongly deprecated.' (ibid. p. 33)

Despite the urgent need to reform Chinese History, the 1953 report did not immediately give rise to any radical revision of the curriculum. Indeed, it was not until the 1960s that local syllabuses for secondary level were introduced to replace the National Government (Guomindang) syllabus of 1941. Before 1974, the existence of separate curricula for the English-medium 'Anglo-Chinese Schools' and for the Chinese-medium 'Chinese Middle Schools' complicated curriculum provisions. 


\section{[INSERT TABLES I \& II ABOUT HERE]}

In the Anglo-Chinese Schools, for example, from the early 1950s onwards Chinese History was taught in Chinese separately from History, taught in English, while in Chinese Middle Schools all subjects were taught in Chinese. The formal separation of history into two distinct subjects was made in 1965 and 1967 respectively when Chinese History became an independent subject in the Certificate of Education Examination (CEE).

However, in terms of their chronological scope, syllabuses for all levels and types of secondary education demonstrated a massive extension of historical coverage back to the most ancient periods of China's past, while the end date of the syllabuses remained fixed at 1911, or was later moved forward to 1945 . While the contemporary period was almost entirely neglected, particular emphasis was given to the history of the Sui, Tang, Sung, Yuan and Ming dynasties (A.D. 581-1643), which taken together are often seen as representing the apogee of Chinese civilization.

That the neglect of contemporary Chinese history was related to official concerns over its political sensitivity was explicitly acknowledged in 1973 by A.G. Brown, the chairman of the Curriculum Development Committee (the old Textbooks and Syllabus Committee):

\footnotetext{
'History is history. We have to wait for a time when subjective political factors and military conflicts are resolved. Only then will we be able to assess the history of modern China in the light of an objective analysis of the available sources. Therefore, in order to avoid getting bogged down in political conflicts, history has to stop in 1945.' (Sing Tao Evening Post, 30 September 1973 translated from Chinese)
}

It is worth noting that, in the case of syllabuses for the History subject, the end date at this time was around 1960 for the section on Europe - though, interestingly, for the section on modern China, the end date was the same as that for the subject of Chinese History: 1945. The exclusion of contemporary Chinese history was clearly intended to exclude the highly sensitive topics of China's civil war and the early history of the People's Republic. Nonetheless, it should be noted that reliable sources concerning the recent history of the PRC were somewhat scarce at this time. Therefore, given the assumption (at that time almost universal) that the central purpose of studying history was simply to determine 'what happened in the past', there were also quite genuine academic reasons for this omission. 
In the 1950s, the possibility of including Hong Kong history in 'Chinese History' seems not to have been considered by those who drafted the syllabuses and wrote the textbooks. These academics, teachers and textbook writers were part of an exiled scholarly community whose membership spanned the Taiwan Strait and extended overseas. Perhaps the most influential of all the historians exiled from mainland China following the Civil War was the conservative traditionalist, Qian Mu. Qian was not directly involved in the drafting of school syllabuses or in textbook production. However, as both the founding president of New Asia College (later to become one of the Colleges of the Chinese University of Hong Kong), and as the author of a standard work on China's dynastic history, his influence on curricula for Chinese history both in Hong Kong and Taiwan was considerable. For example, Qian's conception of Chinese culture as the source of Chinese identity and the key to national revival became central to the philosophy of Chinese History education in colonial Hong Kong as in Nationalist Taiwan. He sought to preserve the orthodox Confucian tradition of Chinese historiography (enshrined in the Twenty-four Dynastic Histories, which focused on the doings of the imperial court), combining an annalistic recording of 'facts' with a moralising concern for highlighting the worthiness or otherwise of figures from the national past. Above all, he saw it as essential that, given the homogeneous nature of Chinese culture (as he saw it), the record of Chinese history from the most ancient times should be preserved and handed down in its entirety to succeeding generations. For Qian, this record was nothing less than the repository of China's 'spiritual' essence (Qian, 1989).

These were the attitudes and beliefs that informed the production of syllabuses and textbooks for Chinese History in Hong Kong during the 1950s and 1960s. Among those most closely involved in textbook production were Wong Fuk Luen and Pong Tak Sun, the owners of two local publishing companies (who also wrote their own Chinese History textbooks), and Sun Kwok Tung, a professor at the Chinese University of Hong Kong (CUHK). The textbooks written by Wong (New Edition of Chinese History), Sun (Chinese History) and Pong (Chinese History) were the best selling Chinese History textbooks in the 1960s, 1970s and 1980s. They were characterised by a dry and factual approach, and by a conservative and anti-Communist bias. Neglect of the history of contemporary China or Hong Kong suited these writers - since modern Chinese and local history were peripheral to the narrative of China's glorious dynastic past. As Luk puts it, the curriculum for Chinese subjects (language and history), established during the 1950s and 1960s, taught 
'generations of Hong Kong Chinese pupils... to identify themselves as Chinese, but relating that Chineseness to neither contemporary China nor the local Hong Kong landscape. It was a Chinese identity in the abstract, a patriotism of the émigré, probably held all the more absolutely because it was not connected to tangible reality.' (Luk, 1991, p. 668)

However, this curriculum was far from an exercise in pro-colonial propaganda. The local subject community, which included officials, teachers and textbook writers, but was led by University scholars, played the key role in defining the nature of Chinese History. The outcome was that the syllabuses and textbooks reflected these scholars' highly traditionalist and, arguably, Han-centred agenda. Their disdain for local and contemporary history allowed them to pursue this agenda without provoking undue disquiet amongst government officials (most of whom - as expatriates - were unable to read for themselves the Chinese teaching materials). Hence, in this period, the subject community assumed a collaborative role vis-a-vis the colonial government. They were allowed to assume the role of guardians of Chinese culture in exchange for producing a depoliticised and decontextualised curriculum. This role well suited the socio-political of Hong Kong conditions in the fifties and sixties.

The focus on ancient periods and the neglect of the local context were not unique to Hong Kong: the same was true of the history curriculum in Nationalist Taiwan during this period. There, a local community with a much more profound sense of its own distinctiveness than Hong Kong's largely refugee population was also required to identify with a monolithic, homogenous vision of China, but one additionally coloured by Nationalist propaganda. De-politicised, colonial Hong Kong was by contrast something of a sanctuary for conservative Chinese scholars thoroughly disillusioned by the current state of China - Communist or Nationalist.

\section{Chinese History - the untouchable subject, 1974-96}

In 1974, the distinct curricula for Anglo-Chinese and Chinese Middle schools were abolished, and all secondary schools adopted the same curriculum at CEE level. This reform in itself did not lead to any major changes to the Chinese History curriculum, since the differences between the curricula were, by this stage, already minimal. However, the change was part of ongoing government efforts to restructure the secondary school curriculum to meet the needs of a system rapidly evolving_from provision for a privileged elite towards mass access. The creation of the Curriculum Development Committee (CDC) in 1973 was 
intended to facilitate curricular rationalisation and reform. A.G. Brown, the chairman of the new body, began to formulate plans to integrate Economic and Public Affairs, Geography, History and Chinese History into one subject, Social Studies, to be taught at junior secondary level. This proposal was inspired by the recent introduction of Social Studies as a subject in some schools in America and Britain, and was seen by its proponents as a progressive move away from the dry academic emphasis of the traditional humanities subjects, and towards a more stimulating, free-ranging, skills-oriented approach (Morris, McClelland and Wong, 1997).

However, when the plan was announced in March 1975, it provoked uproar amongst the Chinese History community. The government was accused of trying to weaken the 'Chinese national sentiments' of local students, and on 7 March, the Oriental Daily devoted its entire front page to attacks on the proposal by CUHK professors and prominent local teachers. Sun Kwok Tung of CUHK, a leading textbook author, declared that

the plan [to introduce Social Studies) constituted 'a conspiracy by the colonial government to carry out colonial education', and warned that 'this integration will weaken students' sense of their Chinese identity and nationality. Social Studies aims to enhance students' sense of belonging to Hong Kong, and this objective itself is incorrect, since as Hong Kong Chinese we should not only have Hong Kong in our minds.

Szeto Wah, the Chairman of the Professional Teachers' Union (PTU), who was to earn an 'anti-China' label from Beijing in 1989 as a result of his pro-democracy activism, also attacked the proposal as a colonial plot:

'This integration [of humanities subjects in the new Social Studies curriculum]... is another form of colonial education. In weakening students' knowledge of China and their nationalist sentiment, the government aims at transforming Chinese into Hongkongese.'

The chairman of another teachers' union, Lam Wah Sun, complained that by reducing the amount of time devoted to Chinese history, the proposed Social Studies syllabus would make it impossible to teach 'the 5,000 years of Chinese History'.

There is no evidence whatsoever to suggest that the Social Studies proposal was a colonial conspiracy to 'de-sinify' Hong Kong's students. However, as a result of these vehement protests, the ED rapidly backtracked and Chinese History's status as an independent subject was preserved. Moreover, later that same year (1975), the CDC 
recommended that the subject be made compulsory at junior secondary level. A teaching syllabus was issued which reinforced the traditional emphasis on dynastic history, centred on the imperial court, and supplemented by topics related to Chinese cultural history.

The following 20 years saw almost no significant changes to the formal curriculum for Chinese History. The only change of any importance was a gradual extension of the chronological scope of the syllabuses, following the agreement between Britain and China over Hong Kong's retrocession, to include more contemporary Chinese history. However, the focus of the curriculum remained on the ancient period, the textbooks continued to be dry and moralising, and - crucially - the style of assessment in public examinations remained basically unaltered - a test of pupils' factual recall in the form of essay and multiple choice questions.

At the same time, the curriculum for the subject of History was undergoing substantial changes, as curriculum developers, influenced by pedagogical trends overseas (particularly in Britain) sought to move away from chronological narrative towards a more thematic approach, and began to introduce document-based questions into their examinations. As a result of their efforts to make the subject more relevant to local students, the History curriculum increasingly trespassed on territory that should have fallen under the remit of Chinese History. In particular, more and more modern Chinese history was included in History syllabuses (though the emphasis tended to be on China's external relations), and more controversially - moves were made to introduce Hong Kong's history into the curriculum for the History subject. During this period, many of those responsible for History curriculum development became increasingly frustrated by what they saw as the backward approach favoured by Chinese History teachers, who they perceived as hampering reform of history education in general. Some began to talk amongst themselves of creating a single Chinese-medium history subject, so that overlapping content could be eliminated, and the teaching of Chinese history could be reformed and revitalised to make it more relevant and interesting for students (Vickers, 2000, Chapters 7-9).

However, to those concerned with the Chinese History curriculum, the independent status of their subject was sacrosanct. Meanwhile, neither the committees responsible for the Chinese History curriculum, nor those responsible for History, were subject to any interference from the colonial government following the 1975 furore over Social Studies (Vickers, 2000). But while their colleagues on the History subject committees in the CDC and the Hong Kong Examinations Authority (HKEA) energetically promoted reforms both to pedagogy and content, the Chinese History subject committees introduced only minimal 
changes. According to a professor of Chinese History who was chairman of the HKEA Sixth-form Chinese History Subject Committee for over twenty years, there was 'nothing wrong with Chinese History... The teaching methods can change, but not the subject matter.' (interview, 18 April 2000). A former Principal Inspector for Humanities Subjects at the government's Advisory Inspectorate also claimed that 'members of the subject committee think that Chinese History should not be fragmented. Its entire development should be studied in order to bring out the essence of Chinese History' (interview, 9 August 1999). The Chinese History community therefore adopted a reactive role and successfully defended their subject from any attempt to change its role and status.

\section{Chinese History and Hong Kong's political transition}

Paradoxically, the Chinese History curriculum has undergone significant changes in recent years, and particularly in the four years since Hong Kong's retrocession. Even before 1997, several minor alterations to syllabuses and textbooks revealed a growing concern on the part of ED officials and textbook publishers to ensure that content offensive to the government of the PRC was avoided. In the case of Chinese History, these changes eventually amounted to a tacit acceptance of mainland orthodoxy with respect to certain key issues. The PRC thus came, informally, to exercise the authority to dictate 'correct interpretations' in a manner and to an extent to which the British colonial administration had never aspired.

In October 1990, during the tense period following the Tiananmen Square Massacre of the previous year, a senior ED official was asked the following question by a reporter: 'To what extent has curriculum development relating to History and Chinese History taken into account Beijing's view?' The written reply was ambiguous, reiterating the view stated twenty years earlier by A. G. Brown. It explained:

\footnotetext{
'...the issue of whether or not Beijing's views are taken into consideration in curriculum planning and development relating to History/Chinese History does not really exist. This, however, does not preclude the caution one has to exercise in dealing with contemporary China or current Sino-Hong Kong relations. While there is neither the need nor the ground to "please" Beijing in that specific context, one has to be discreet not to provoke her unnecessarily nor to sow the seeds of discord through reckless handling of subject matter, e.g. the inclusion of biased views or unwarranted comments, etc..' (Draft prepared for DCI (CD) for press interview, 15 October, 1990, Advisory Inspectorate, History Section, ED)
} 
Though curriculum developers for History and Chinese History interviewed by the present authors unanimously denied being subjected to direct political pressure, the statement above suggests that they perceived that they would be held responsible by their superiors for any undue 'bias' or 'unwarranted comments' that were allowed to creep into syllabuses or textbooks. Therefore, officials responsible for Chinese History had to draw their own conclusions, which were also conditioned by their assumption that history must consist of a single, correct 'authorized version'. For example, discussing the decision made in the 1980s to extend the end date of the HKCEE syllabus to 1976, the ex-Chinese History inspector declared that 'the major problem involves drafting the marking schemes, particularly as regards the Cultural Revolution, since no official views on this have yet been established in China' (interview, 4 August 1999). A concern to avoid any commitment to particular interpretations of sensitive issues in post-1949 Chinese history is implicit in the style of examination questions on this period, which evade potential controversy by requiring entirely descriptive, narrative answers:

\footnotetext{
'Give a general description of the process of the Cultural Revolution from May 1966 to the end of 1968.' (HKCEE, 1997)

'Describe the objectives of the Great Leap Forward and the methods used to achieve these objectives in the fields of industry and agriculture.' (HKCEE, 1999)

'Briefly describe the economic reform policies of the Chinese government between 1949 and 1957.' (HKCEE, 2000)
}

Fears concerning the commercial implications of printing material offensive to Beijing prompted textbook publishers to be especially cautious in the run-up to 1997, resulting in varying degrees of 'self-censorship' (Vickers, 2000; Vines, 1998). In order to curb the more extreme manifestations of this phenomenon, the ED issued guidelines in 1997 outlining the changes required for compliance with the 'One China principle' . The list was limited to ostensibly minor alterations to terminology, but even these constituted significant constraints on historical interpretation. For example, the PRC's non-recognition of the 'unequal' Treaty of Nanjing meant that references to Hong Kong as a 'colony' were not allowed. In addition, the phrase 'the Nationalist government moved to Taiwan', referring to the flight of Guomindang forces from mainland China in 1948-9, was also deemed unacceptable, since it might be taken to imply the existence of 'two Chinas' (Meeting minutes, Chinese History Subject Committee (CEE), 11 October 1996). 
The retrocession itself brought more sweeping changes to the curriculum for Chinese History. In his first policy address, Tung Chee Hwa made clear that the promotion of a homogenous and totalising sense of Chinese culture, morality and values (Morris et al, 2000) was central to his educational agenda:

'We will incorporate the teaching of Chinese values in the school curriculum and provide more opportunities for students to learn about Chinese history and culture. This will foster a stronger sense of Chinese identity in our students.' (Hong Kong Government Policy Address, 1997)

Chinese History was the only mainstream school subject whose syllabuses underwent major revisions as a direct consequence of the 1997 handover. These changes essentially involved the addition of a politicised nationalism to the more detached ethnic and cultural 'patriotism' that had previously characterised the subject. Thus a new teaching curriculum issued in 1997 listed as a key aim that of 'cultivating a sense of belonging to the nation and its people', and 'establishing local and national sentiments'. These phrases echo the aims of mainland China's Junior Secondary History Syllabus (1996) which stress the promotion of patriotic education and of love for the socialist motherland, the people, and the CCP. In 1999, with the inclusion in Chinese History of local history, a teaching package for Hong Kong history was produced, which, in contrast to the approach to local history in History syllabuses, explicitly adopted the overriding aim of demonstrating that Hong Kong had been part of China 'from time immemorial'.

In practice, however, these changes involved a far less radical shift for the subject than might at first appear. The local history package, for example, was issued to teachers with a reminder that it was merely an appendix to the main syllabus, and that only after that syllabus had been thoroughly taught should they devote lesson time to Hong Kong history. More fundamentally, by the time of the retrocession there was relatively little contradiction between the ethnic and cultural socialisation that the local Chinese History curriculum had always promoted, and the ethno-cultural nationalism and 'traditional Chinese values' which by then had largely replaced Communism as the guiding ideology of the mainland regime. The terminological changes required as a result of the handover mostly related to the modern period, which was only a very minor part of the syllabuses for the subject. The Chinese History subject community had always kept faith with the 'one China' principle, and Hong Kong's re-unification with the motherland seemed likely to bring enhanced official support for just the sort of cultural conservatism that they had always preached. 


\section{'New History' and the 'betrayal' of Chinese History}

Despite their apparently reasonable grounds for optimism after 1997, those associated with the Chinese History subject were soon confronted with a new threat to their subject's status within the curriculum. This arose from the conflicting priorities of the posthandover government which, as noted above, sought to use the school curriculum both to promote 'national sentiment', and to foster the skills necessary for Hong Kong to succeed in 'the information age'. The former objective implied giving greater emphasis to the teaching of Putonghua, Civics and Chinese History, while the latter pointed to the need for better command of English, 'IT' and generic skills such as problem solving.

It soon became apparent to a number of ED officials that these various priorities could not all be accommodated without a restructuring and integration of the existing fragmented curriculum. An obvious candidate for reform was the history curriculum, with its unique division into two subjects with significant overlap in terms of content (interview with Senior Inspector, March 29, 2000). The continued division of History seemed especially difficult to justify since the move to require most schools to teach in Cantonese meant that the two subjects were now usually taught in the same language. Nonetheless, officials were alive to the political risks associated both with policies of compulsion in general, and with any attempt to reform Chinese History in particular. They therefore began work on a syllabus for a merged 'New History' subject at junior secondary level that would be strictly optional - it would be left entirely to individual schools to decide whether to adopt it, or to continue offering separate History and Chinese History lessons.

The 'New History' plans aroused intense disquiet amongst the Chinese History community and in early 2000 details of this proposal were leaked to the local press. The resulting reports alleged that the 'New History' proposal was an 'unpatriotic' plot to abolish Chinese History. A writer in the Hong Kong Economic Journal compared the 'New History' project to the 1975 Social Studies proposal, accused its proponents of failing to 'erase the taint of colonial education', and, in language that echoed that often used by Tung Chee-hwa, insisted that 'teaching Hong Kong's younger generation to recognise and identify with the culture of the Chinese nation is the most important task of education in Hong Kong' (HKEJ, 8 January, 2000). Identical sentiments pervaded most of the column inches devoted to this controversy in local newspapers over the following months.

The opponents of 'New History' objected principally to two aspects of the proposal: the fact that it would result in less timetable space for the teaching of Chinese history; but 
also, more fundamentally, the very principle of breaking up the continuous narrative of the Chinese past, and then cutting-and-pasting sections of it into a thematically structured global syllabus. A feature article in Ming Pao argued that combining 'Western' and Chinese history within a single subject was analogous to 'extra-marital sex', since China's dynastic history was culturally too different from that of Europe, and could not be studied using a common set of chronological or conceptual categories. Like Qian Mu, this writer saw Chinese History as a discipline fundamentally incommensurable with history as practised, or experienced, in 'the West' (Ming Pao, 20 April, 2000). Two weeks earlier, however, an editorial in the same newspaper had appealed to international precedent to justify its call for national history to be made a compulsory and independent subject in local schools, claiming that this was the practice not only in mainland China and Taiwan, but also in 'many states in America' (Ming Pao, 7 April, 2000).

The stridency with which members of the 'Chinese History Educators' Society', set up in response to the 'New History' proposal, attacked the ED over this issue, belied their sense of disbelief that an administration that preached 'patriotism' could so readily betray them. Their sense of betrayal can only have been heightened when Cheng Kai-ming, a prominent academic widely regarded as a key advisor to the government on educational matters, openly contradicted their main arguments.

\footnotetext{
'Both students and teachers,' he declared, 'generally regard Chinese History as an extremely boring subject... The proper study of Chinese history requires a new method': Some friends do not agree. They believe that every dynasty and every emperor must be studied one by one, and that it is necessary to memorise every era and every event. From time immemorial [they say], this has been a way of preserving the national culture. If it is not done like this, then tradition will be destroyed and individuals will have no cultural identity.
}

'[But] times change,... and the study of Chinese history must also change. The mainland and Taiwan have both been exploring new ways of teaching Chinese history... There is no reason why Hong Kong cannot also move in a new direction.' (Cheng Kai-ming, writing in Ming Pao, 3 April, 2000)

However, the government as a whole has so far failed to resolve the 'New History' controversy in favour of one or the other side. ED officials remain split, and Chinese History teachers and their supporters continue to demand a promise from the Chief Executive that the status of their subject will be protected. Such a promise has not been forthcoming, but neither has there been any firm or consistent support for those in the ED who want to 
promote the integration of History and Chinese History. Meanwhile, the dispute has distracted attention from other, arguably far more crucial, aspects of the sweeping educational reforms that the government is currently considering. Like the colonial government in 1975, the current administration has apparently been paralyzed by its fear of political controversy, reinforced by a belated realisation of the weakness of its own legitimacy. Its attempts to abandon the consensual style of policymaking that typified the colonial regime, in favour of a more radical and decisive approach, have only served to highlight the risks involved in alienating vocal and well-organised interest groups. And no group has proved more vocal, or more effective in gaining media attention, than the Chinese History subject community, which has taken upon itself the role of the guardian of 'national' education in the SAR.

In the course of the ongoing 'New History' controversy, almost no-one has noted the irony that Chinese History in Hong Kong, which is now defended on patriotic grounds, is itself a unique product of Hong Kong's colonial history. It was the predominance in Hong Kong of English-medium instruction, combined with the British administration's unwillingness to countenance the use of 'subversive' mainland textbooks, that led to the creation of a locally-drafted, vernacular curriculum for Chinese history. Moreover, it was the political weakness of the colonial government that ensured the preservation into the $21^{\text {st }}$ century of Chinese History as an independent subject. Far from forcing curriculum developers to promote 'colonial values', the British authorities created broad curricular parameters within which conservative scholars were able to promote their own ideological agenda. The outcome was an 'invented tradition' of depoliticised, ethno-cultural nationalism whose colonial parentage was obscured or quickly forgotten, and which rapidly acquired symbolic status for many 'patriots' in the local community. The existence of Chinese History as a separate subject thus became a political fact that both colonial and post-colonial regimes have so far found it impossible to shift.

\section{Conclusion}

It is clear that, far from 'devaluing indigenous culture', colonial curriculum policy in Hong Kong had the opposite effect of creating a school subject that presented a totalising, homogenous, quasi-religious vision of the Chinese past. It could be argued that it has been convenient, from a British point of view, for local people to continue to identify themselves as Chinese rather than British, not least when it came to the issue of whether or not they 
should be granted British passports prior to Hong Kong's retrocession. However, there is no evidence to suggest that Chinese History was created as part of any colonial conspiracy to deny the claims of Hong Kong people to British nationality, just as there is no evidence that Hong Kong people have at any time wished to regard themselves as British rather than Chinese or 'Hongkongese'. Pennycook (1998), Said $(1991,1995)$ and others who continue to view colonial education as a 'hegemonising' plot to alienate the 'native' from his own culture, fail to account both for the apparent lack in Hong Kong of any 'hegemonical' intent (at least in the cultural sphere) on the part of the British, and for the weakness rather than the strength of their control over the education system.

An uncritical acceptance of stereotypical views of 'colonialism' also obscures the considerable similarities between the colonial and post-colonial regimes, in particular with respect to the difficulties they have encountered in their attempts to reform local schooling. The fragile, collaborative foundations of governmental authority have made it especially difficult for civil servants to take on an interest group as cohesive and determined as that formed by the supporters of Chinese History. In contrast to the subject of History, Chinese History appears to conform more closely to Goodson's model of a subject community intent on preserving and enhancing its traditional academic credentials, and characterised by strong bonds of common interest linking schoolteachers, university academics and curriculum developers. The role played by this subject community has nonetheless been subject to change. In the process of Chinese History's curriculum development its role has changed from a collaborative one (from the 1950s to about 1974), to a reactive, defensive one (197597), and thereafter to a fiercely proactive role. In these respective roles the subject community has projected itself as the guardian of Chinese culture (first period), the guardian of the Chinese History subject and discipline (second period), and (currently) the guardian of ‘national education' more broadly conceived.

It is likely that only an administration confident not merely of its patriotic credentials, but also of its popular support, would have the political courage to tackle an interest group that has been so successful in establishing its nationalist pedigree. Whether, or for how long, the Chinese History community can resist the pressure to reform their curriculum and, in particular, their conceptions of what constitutes a valid focus for pedagogy and assessment may therefore depend largely on whether or when Hong Kong acquires a government with a stronger popular mandate than the current one. However, any government that attempts to reform Chinese History is taking on a community bound not simply by self-interest, but and this is a factor neglected by Goodson's model - a band of true believers. 
Table I

Anglo-Chinese Schools: Development of the Chinese History Curriculum from 1950s to 1974

\begin{tabular}{|l|l|l|l|}
\hline Year & $\mathbf{F . 1 - 3}$ & $\mathbf{F . 4 - 5}$ & $\mathbf{F . 6 - 7}$ \\
\hline 1950 s & $\begin{array}{l}\text { Chinese History and } \\
\text { Chinese Literature } \\
\text { were one subject }\end{array}$ & $\begin{array}{l}\text { Chinese History and } \\
\text { Chinese Literature } \\
\text { were one subject }\end{array}$ & $\begin{array}{l}\text { Chinese History, Chinese } \\
\text { Language and Chinese } \\
\text { Literature were one subject }\end{array}$ \\
\hline 1956 & & $\begin{array}{l}\text { Chinese History offered as an } \\
\text { independent subject in } \\
\text { 'O'level \& 'A'level exams }\end{array}$ \\
\hline 1960 & $\begin{array}{l}\text { Chinese History as an } \\
\text { independent subject }\end{array}$ & $\begin{array}{l}\text { Chinese History as an } \\
\text { independent subject in } \\
\text { the Certificate of } \\
\text { Education Exam (CE) }\end{array}$ & $\begin{array}{l}\text { 'O' 'level was abolished. Only } \\
\text { 'Available Chinese History }\end{array}$ \\
\hline 1965 & & $\begin{array}{l}\text { Anglo-Chinese School } \\
\text { and Chinese Middle } \\
\text { School followed the } \\
\text { same CEE Chinese } \\
\text { History syllabus }\end{array}$ \\
\hline 1974 & & \multicolumn{2}{|l}{} \\
\hline
\end{tabular}

(23) 
Table II

Chinese Middle Schools: Development of the Chinese History Curriculum from 1950s to 1974

\begin{tabular}{|c|c|c|c|}
\hline Year & F.1-3 & F.4-5 & F.6 \\
\hline $\begin{array}{l}\text { 1950s } \\
\text { (followed the } \\
1941 \text { History } \\
\text { syllabus of } \\
\text { China in which } \\
\text { History } \\
\text { comprised both } \\
\text { Chinese } \\
\text { History and } \\
\text { World } \\
\text { History.) }\end{array}$ & $\begin{array}{l}\text { - F.1-2: } \\
\text { focus on Chinese } \\
\text { History } \\
\text { - F.3: focus } \\
\text { on World History }\end{array}$ & \multicolumn{2}{|c|}{$\begin{array}{l}\text { F.4:Chinese History } \\
\text { F.5:Chinese History \& World History } \\
\text { F.6:World History } \\
\text { No CEE till } 1965 \\
\text { - Only the Higher-level exam for F.6 was } \\
\text { available before the introduction of CEE for } \\
\text { Chinese Middle Schools. } \\
\text { - The Higher-level exam was introduced in } \\
\text { 1952. The subject of History incorporated } \\
\text { both Chinese History \& World History. }\end{array}$} \\
\hline 1962 & $\begin{array}{l}\text { Chinese History } \\
\text { as an independent } \\
\text { subject }\end{array}$ & & \\
\hline 1965 & & $\begin{array}{l}\text { CEE first introduced. The } \\
\text { subject of } \quad \text { History } \\
\text { incorporated both Chinese } \\
\text { History \& World History. }\end{array}$ & $\begin{array}{l}\text { Chinese History } \\
\text { as an } \\
\text { independent } \\
\text { subject in the } \\
\text { Higher-level } \\
\text { exam. }\end{array}$ \\
\hline 1967 & & $\begin{array}{l}\text { Chinese History as an } \\
\text { independent subject in CEE }\end{array}$ & \\
\hline 1974 & & $\begin{array}{l}\text { Chinese Middle School and } \\
\text { Anglo-Chinese School } \\
\text { followed the same CEE } \\
\text { Chinese History syllabus }\end{array}$ & \\
\hline
\end{tabular}




\section{References}

Altbach, G. and Kelly, P. (1978) Education and Colonialism (New York, Longman).

Asiwaju, A.I. (1975) Formal Education in Western Yorubaland, 1889-1960: A Comparison of the French and British Colonial Systems, Comparative Education Review, 19 (3) pp.434-450.

Carnoy, M. (1974) Education as Cultural Imperialism (New York, McKay).

Education Department (1953) The Report of the Chinese Studies Committee (Hong Kong, Hong Kong Government Printer).

Cha, Yun-kyung (1992) The origins and Expansion of Primary School Curricula, 1800-1920, in: J. Meyer, D. Kamens and A. Benavot (Eds) School Knowledge for the Masses: World Models and Curricular Categories in the Twentieth Century (London, Falmer Press).

Gifford, P. and Weiskel, T. (1971) African Education in a Colonial Context, in: Prosser Gifford and Wm. Roger Louis (Eds) France and Britain in Africa (New Haven, Yale University Press).

Goodson, I. F. (1994) Studying Curriculum (Buckingham, Open University Press).

Goodson, I. F. (1995) The Making of Curriculum (London, The Falmer Press)

Hong Kong Examinations Authority (1997, 1999, 2000) Marking Schemes (CEE) (Hong Kong, Hong Kong Government Printer).

Hong Kong Government (1997) Policy Address (Hong Kong, Hong Kong Government Printer)

Husbands, C. and Pendry, A. (1992) Whose History? School History and the Naitonal Currriculum (Norwich, UEA).

Kelly, G. and Altbach, P. (1984) Education and the Colonial Experience (N.J., Transaction).

Lau, C.K. (1997) Hong Kong's Colonial Legacy (Hong Kong, The Chinese University Press).

Luk, H.K. (1991) Chinese Culture in the Hong Kong Curriculum: Heritage and Colonialism, Comparative Education Review, 35 (4), pp.650-668.

Meyer, J.W., Kamens, D.H. and Benavot, A. (1992) School Knowledge for the Masses: World Models and Curricular Categories in the Twentieth Century (London, Falmer Press)

Morris, P., Kan, F., and Morris, E. (2000) Education, Civic Participation and Identity: continuity and change in Hong Kong, Cambridge Journal of Education, 30 (2) pp. 243-262. 
Morris, P., McClelland, J. and Wong, P.M. (1997) Explaining Curriculum Change: Social Studies in Hong Kong, Comparative Education Review, 41 (1) pp. 27-43.

Musgrove, F. (1955) History Teaching within a Conflict of Cultures, History, 15 (140), p. 300.

Pennycook, A. (1998) English and the Discourses of Colonialism (London, Routledge).

Phillips, R. (1998) History Teaching, Nationhood and the State: A Study in Educational Politics (London, Cassell).

Qian, Mu. (1989) Nation and Culture (Taiwan, Dong Da Publishing Co). [in Chinese]

Robinson, R. (1986) The excentric theory of imperialism: with or without empire, in :Mommsen and Osterhammel (Eds) Imperialism and After (London, German Historical Institute) ,pp. 267-289.

Said, E. (1991, 1995) Orientalism (London, Penguin).

Said, E. (1994) Culture and Imperialism (UK, Vintage)

Slater, J. (1989) The Politics of History Teaching a humanity dehumanized? Special Professorial Lecture (Institute of Education, University of London).

Sweeting, A.E. (1991) 1991 Politics and the Art of Teaching History in Hong Kong. Teaching History, 64, pp. 30-37.

Vickers, E. (2000) History as a School Subject in Hong Kong: 1960s-2000 (HKU, unpublished $\mathrm{PhD}$ thesis).

Vines, S. (1998) Hong Kong: China’s New Colony (London, Aurum Press). 